\title{
Inhibition of a novel specific neuroglial integrin signaling pathway increases STAT3-mediated CNTF expression
}

\author{
Matthew P Keasey ${ }^{1}$, Seong Su Kang ${ }^{1}$, Chiharu Lovins ${ }^{1}$ and Theo Hagg ${ }^{1,2^{*}}$
}

\begin{abstract}
Background: Ciliary neurotrophic factor (CNTF) expression is repressed in astrocytes by neuronal contact in the CNS and is rapidly induced by injury. Here, we defined an inhibitory integrin signaling pathway.

Results: The integrin substrates laminin, fibronectin and vitronectin, but not collagen, thrombospondin or fibrinogen, reduced CNTF expression in C6 astroglioma cells. Antibodies against av and $\beta 5$, but not $a 6$ or $\beta 1$, integrin induced CNTF. Together, the ligand and antibody specificity suggests that CNTF is repressed by av $\beta 5$ integrin. Antibodies against Thy1, an abundant neuronal surface protein whose function is unclear, induced CNTF in neuron-astrocyte co-cultures indicating that it is a neuroglial CNTF repressor. Inhibition of the integrin signaling molecule Focal Adhesion Kinase (FAK) or the downstream c-Jun N-terminal kinase (JNK), but not extracellular regulated kinase (ERK) or P38 MAPK, greatly induced CNTF mRNA and protein expression within 4 hours. This selective inhibitory pathway phosphorylated STAT3 on its inhibitory ser-727 residue interfering with activity of the pro-transcription Tyr-705 residue. STAT3 can activate CNTF transcription because it bound to its promoter and FAK antagonist-induced CNTF was reduced by blocking STAT3. Microinjection of FAK inhibitor directly into the brain or spinal cord in adult mice rapidly induced CNTF mRNA and protein expression. Importantly, systemic treatment with FAK inhibitors over 3 days induced CNTF in the subventricular zone and increased neurogenesis.
\end{abstract}

Conclusions: Neuron-astroglia contact mediated by integrins serves as a sensor to enable rapid neurotrophic responses and provides a new pharmacological avenue to exploit the neuroprotective properties of endogenous CNTF.

Keywords: Astrocyte, Ciliary neurotrophic factor, Focal adhesion kinase, Integrin, Intercellular communication, Mice, Neurogenesis, Neuron, Pharmacological, Transcriptional gene regulation

\section{Background}

Endogenous CNTF regulates the development of oligodendrocytes [1] and some neurons [2], synaptic function [3], and adult CNS neurogenesis [4,5]. CNTF treatment is neuroprotective in many animal models [6-10], and promotes retinal ganglion cell regeneration [11,12] and remyelination [13]. Even so, clinical trials failed due to low penetration of CNTF into the CNS and systemic side effects after subcutaneous injections [14]. CNTF is almost exclusively expressed in the nervous system, suggesting

\footnotetext{
* Correspondence: theo.hagg@louisville.edu

'Kentucky Spinal Cord Injury Research Center, Department of Neurological Surgery, University of Louisville, Louisville, KY 40292, USA

${ }^{2}$ Pharmacology and Toxicology, University of Louisville, Louisville, KY 40292
} USA

\section{Biomed Central}

(c) 2013 Keasey et al.; licensee BioMed Central Ltd. This is an Open Access article distributed under the terms of the Creative Commons Attribution License (http://creativecommons.org/licenses/by/2.0), which permits unrestricted use, distribution, and reproduction in any medium, provided the original work is properly cited. that its pharmacological induction might solve these problems. In the CNS, CNTF is produced at very low levels primarily by astrocytes [15] but little is known about mechanisms that regulate its expression. We found that a cAMP-reducing dopamine D2 agonist induces CNTF in the brain but not the spinal cord [5], indicating the need to find more universal regulation mechanisms.

The expression of CNTF is rapidly and robustly induced in astrocytes upon brain injury [16] and stroke [17], where it serves a neuroprotective role [18], as it does in an experimental autoimmune encephalomyelitis (EAE) model [19] and the retina [20]. We found that glial CNTF is repressed by integrins and, conversely, that loss of neuron-astroglial interaction increases CNTF in vitro 
and in the mouse striatum after ischemic or excitotoxic neuronal loss [18].

Integrins are a group of 24 heterodimer receptors with alpha and beta subunits binding extracellular matrix (ECM) proteins as adhesion partners [21]. The neuronal ligands that bind astroglial integrins to regulate CNTF are unknown. Neurons do not make most of the classical ECM molecules although they express laminin isoforms $[22,23]$. Thy-1, whose function is unknown, is highly expressed by adult neurons [24] and is a ligand of $\alpha v \beta 3$ [25] and $\alpha v \beta 5$ integrins [26] which are expressed by astrocytes and astroglioma cells $[27,28]$. Integrins signal through focal adhesion kinase (FAK) which can signal downstream to the ERK, p38 and JNK pathways [29]. The intracellular signaling pathways that regulate CNTF are unknown. The transcription factor Sox-10 regulates CNTF expression in Schwann cells [30] but is not present in astrocytes [31]. IL6 and CNTF itself induce CNTF expression [12,18], suggesting a potential role of STAT3, which is downstream of their gp130 receptor [32,33].
We set out to identify the CNTF-repressing signaling pathway from neuronal ligand to astroglial transcription factor, and whether its pharmacological inhibition would increase functional CNTF using adult SVZ neurogenesis as an outcome measure.

\section{Results}

\section{Glial CNTF is repressed through av $\beta 5$ integrin}

To identify which integrins repress CNTF, we first tested various ECM ligands with known differential integrin binding partners $[21,34,35]$ in rat C6 astroglioma cells which express CNTF [36]. The advantage of the C6 cell is the purity, consistency and ease of the cultures compared to primary astrocytes. Moreover, the low CNTF expression by $\mathrm{C} 6$ cells makes them a good cell model to study changes in CNTF expression whereas the very high levels in cultured primary astrocytes combined with the half-life of 7 hours of the CNTF mRNA make it more difficult to detect modest changes under acute conditions. CNTF mRNA was decreased by $\sim 25 \%$ when cells were cul-
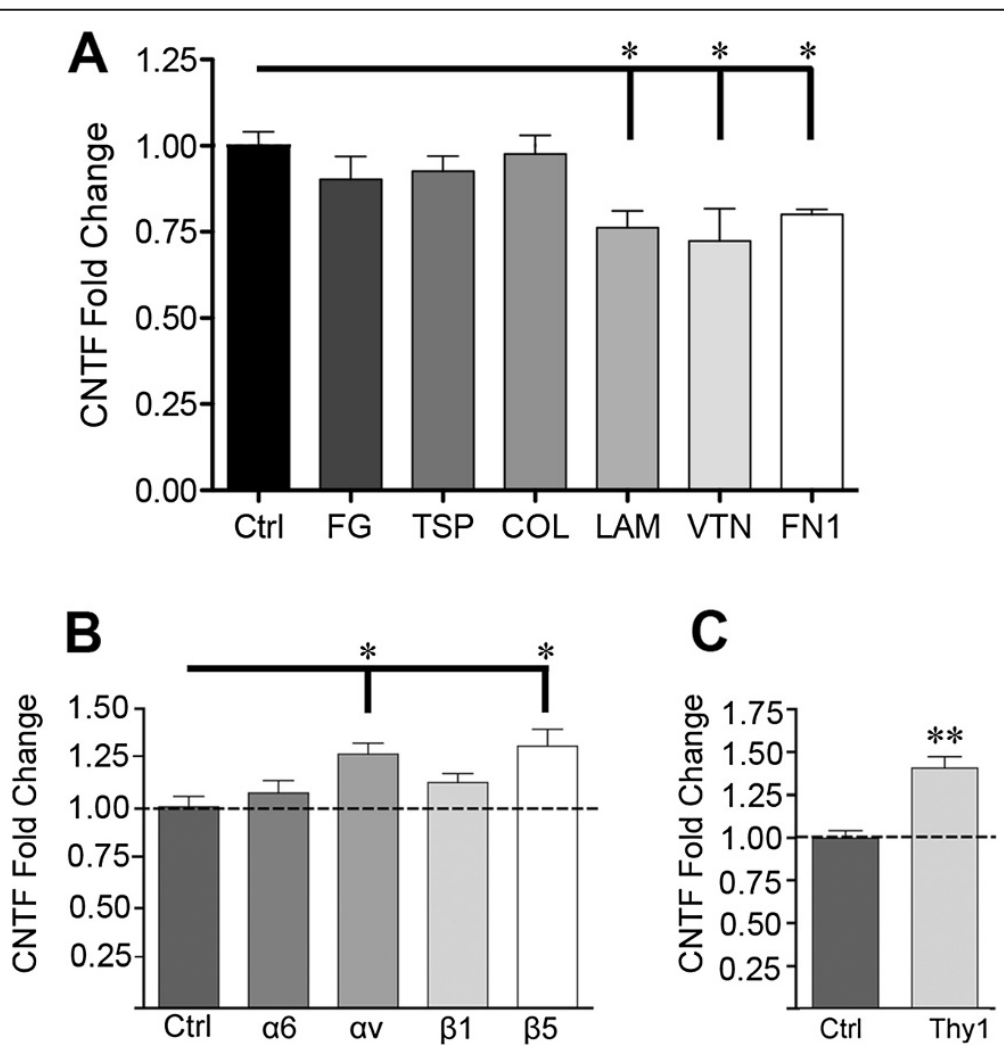

Figure 1 CNTF is repressed by ECM and specific av $\beta 5$ integrin and neuronal Thy- 1 ligand. A) C6 astroglioma cells grown for $4 \mathrm{~h}$ on laminin (LAM), fibronectin (FN1) and vitronectin (VTN) had lower levels of CNTF mRNA compared to poly-d-lysine control (Ctrl, set at 1.00) as quantified by qRT-PCR. Fibrinogen (FG), thrombospondin (TSP), and collagen (COL) had no significant effect. Because of the binding specificity this suggests that a limited number of integrins repress CNTF. B) Neutralizing antibodies against av or $\beta 5$, but not a6 or $\beta 1$ induce CNTF mRNA expression relative to $\operatorname{lgG}(\mathrm{Ctrl})$ in $\mathrm{C} 6$ cells after 4 hours. Antibody selection was guided by elimination of unlikely candidates (Table 1). The $\beta 5$ subunit is only found in $a v \beta 5$. C) Neutralizing antibody against Thy-1, an av $\beta 5$ ligand, induces CNTF mRNA expression in primary astrocyteneuron co-cultures compared to lgG (Ctrl). Data represent means ( \pm SEM) of 3-4 (A) or $6(\mathbf{B}, \mathbf{C})$ independent experiments and are fold changes expressed relative to controls. 
tured for 4 hours on laminin, fibronectin or vitronectin (Figure 1A). CNTF expression was not affected by fibrinogen, thrombospondin and collagen. We therefore excluded their integrin binding partners from further study $(\alpha 1 \beta 1$, $\alpha 2 \beta 1, \alpha 3 \beta 1, \alpha 4 \beta 1, \alpha 5 \beta 1, \alpha 10 \beta 1, \alpha 11 \beta 1$, and $\alpha v \beta 3$; Table 1). We also excluded leukocyte-specific integrins from further consideration (Table 1 ) as well as $\alpha 7, \alpha 8, \beta 6$ whose presence in astrocytes is currently unknown (Pubmed search). Finally, we did not test $\beta 8$ antibodies as mature astrocytes have down-regulated $\alpha v \beta 8$ integrin [37] and we could not obtain a suitable function-blocking antibody against rat. Having narrowed down potential integrins that might affect CNTF expression, function blocking antibodies were used against $\alpha 6, \alpha v, \beta 1$ and $\beta 5$ integrin subunits. Freshly plated C6 cells incubated for 4 hours with $\alpha \mathrm{v}$ and $\beta 5$ integrin antibodies had $28 \%$ and $38 \%$ more CNTF mRNA, respectively, compared to no antibody or purified isotype specific IgG (Figure 1B). In contrast, $\alpha 6$ and $\beta 1$ integrin antibodies did not significantly alter CNTF expression. Interestingly, the only integrin with a $\beta 5$ subunit is $\alpha v \beta 5$, suggesting that it may be specifically involved in inhibiting CNTF expression.

\section{Astroglial CNTF is repressed by neuronal Thy-1}

The surface protein Thy- 1 is enriched in neurons throughout the CNS [40,41] and binds $\alpha v \beta 5$ integrin [25], but its role in the brain is unknown. Primary cortical neurons were incubated with Thy-1 blocking or IgG control antibodies prior to seeding onto primary astrocyte monolayers. Thy-1 antibody increased CNTF expression by 40\% (Figure 1C). This suggests that neuronal Thy-1 is an

Table 1 Process to define which integrins repress CNTF

\begin{tabular}{|c|c|c|c|c|c|c|c|c|}
\hline Integrin & FG & TSP & COL & LAM & VTN & FN1 & Leukocyte & Antibody \\
\hline$\alpha 1 \beta 1$ & & & $i, i i, i i i$ & i, ii, iii & & & & $\beta 1$ \\
\hline$\alpha 2 \beta 1$ & & $i, i i i$ & $i, i i, i i i$ & i, ii, iii & & ii & & $\beta 1$ \\
\hline$a 3 \beta 1$ & & i, ii, iii & & i, iii & & ii & & $\beta 1$ \\
\hline$a 4 \beta 1$ & & $i, i i i$ & & & & i, ii, iii & $x$ & $\beta 1$ \\
\hline$a 4 \beta 7$ & & & & & & i, ii, iii & $x$ & \\
\hline$a 5 \beta 1$ & $i i$ & $i i i$ & & & & i, ii, iii & & $\beta 1$ \\
\hline$a 6 \beta 1$ & & $i i i$ & & i, ii, iii & & & & $a 6, \beta 1$ \\
\hline$a 6 \beta 4$ & & & & i, ii, iii & & & & $\beta 6$ \\
\hline$a 7 \beta 1$ & & & & i, ii, iii & & & & $\beta 1$ \\
\hline$a 8 \beta 1$ & & & & & & i, ii, iii & & $\beta 1$ \\
\hline a9ß1 & & & & & & & $x$ & $\beta 1$ \\
\hline a10ß1 & & & $i, i i i$ & & & & & $\beta 1$ \\
\hline$\alpha 11 \beta 1$ & & & $i, i i, i i i$ & & & & & $\beta 1$ \\
\hline$a v \beta 1$ & & & & & ii & i, ii, iii & & $\beta 1$ \\
\hline avß3 & $i, i i, i i i$ & $i, i i, i i i$ & & ii & i, ii, iii & i, ii, iii & & \\
\hline$a v \beta 5$ & & & & & i, ii, iii & ii & & $a v, \beta 5$ \\
\hline avß6 & & & & & & i, ii, iii & & av \\
\hline$a v \beta 8$ & & & & & & ii & & av \\
\hline $\operatorname{ad} \beta 2$ & & & & & iii & iii & $x$ & \\
\hline$a L \beta 2$ & & & & & & & $x$ & \\
\hline$a m \beta 2$ & i, ii, iii & & & & & & $x$ & \\
\hline $\operatorname{ax\beta 2}$ & $i, i i, i i i$ & & iii & & & & $x$ & \\
\hline$a E \beta 7$ & & & & & & & $x$ & \\
\hline allb $\beta 3$ & $i, i i, i i i$ & $i, i i, i i i$ & & & i, ii, iii & i, ii, iii & & \\
\hline \multicolumn{9}{|c|}{$\begin{array}{l}\text { We applied the following process to help us to decide which subunit blocking antibodies to test and which integrins most likely repress CNTF. When "italics" } \\
\text { appears in a row, that specific integrin is considered unlikely to be involved in repressing CNTF. We first used the data from the ECM substrate experiment } \\
\text { (Figure 1A) and the known integrin binding partners to eliminate potential integrins involved in repressing CNTF. Thus, fibrinogen (FG), thrombospondin (TSP), } \\
\text { and collagen (COL) had no significant effect on CNTF mRNA levels in C6 cells, as indicated by "italics" in the row of their known integrin partners. The numbers in } \\
\text { the cells indicate the following articles that list the specific ligand - integrin relationship: i) Humphries et al., [34] ii) Plow et al. [38], and iii) Takada et al., [39]. } \\
\text { Laminin (LAM), vitronectin (VTN), and fibronectin (FN) significantly reduced CNTF expression, as indicated by "bold" numbers in the respective columns. Next, to } \\
\text { further help with antibody selection, we eliminated all leukocyte-specific integrins [21]) as they are not present on glial cells (second to last column). Lastly, the } \\
\text { results from the antibody experiment (Figure 1B) were used to eliminate a number of } \beta 1 \text { - and a6-containing integrins ("italics" letters in the last column), leaving } \\
\text { three candidates which potentially repress CNTF ("bold" letters in the last column). }\end{array}$} \\
\hline
\end{tabular}


inhibitor of astroglial CNTF expression. We did not test antibodies against laminin because the integrin binding motif is unknown. Vitronectin [42] and fibronectin [43] are not present in neurons.

\section{Glial Focal Adhesion Kinase represses CNTF mRNA and protein}

FAK is the best-known kinase associated with integrin signaling $[29,44]$. C6 cells incubated with the FAK antagonist (FAKi) PF573228 for 4 hours showed a more than 3 fold induction of CNTF mRNA expression (Figure 2A). FAK activity was clearly decreased by the inhibitor as assessed by western blotting for phosphorylated FAK (Tyrosine397, here on pFAK; Figure 2B). In the same protein extracts, CNTF was robustly increased by the inhibitor (Figure 2C). Wounding the C6 cells by mechanical dissociation induced CNTF expression within 2 hours (Figure 2D). CNTF mRNA levels returned to baseline after 6 hours despite similar cell survival between 2 and 6 hours (as defined by MTT assay and trypan blue counts; data not shown). This suggests that both induction and repression of CNTF occur rapidly. FAK inhibition of injured cells did not cause further increases in CNTF
mRNA (Figure 2E), suggesting that modulation of FAK plays a central role in the injury-induced disinhibition of CNTF. These experiments identified FAK as a molecular target to pharmacologically increase CNTF protein expression.

\section{FAK-JNK activation mediates repression of CNTF}

Downstream targets of FAK include ERK [45], JNK [46,47] and p38 MAPK [48]. Pharmacological inhibition of JNK induced CNTF mRNA expression in C6 astroglioma cells more than 3 fold, whereas antagonists of ERK or p38 did not significantly alter CNTF expression (Figure 3A). Moreover, FAK inhibitor treatment inactivated JNK as shown by a reduction in phosphorylated JNK (pJNK) protein (Figure 3B). These data indicate that integrin-mediated CNTF repression occurs through a specific FAK-JNK signaling pathway.

\section{FAK represses CNTF by inhibiting STAT3 through the ser- 727 residue}

Activation of STAT3 transcriptional activity depends upon phosphorylation at a tyrosine residue (Tyr-705) [49,50]. STAT3 is inhibited by phosphorylation of a serine residue
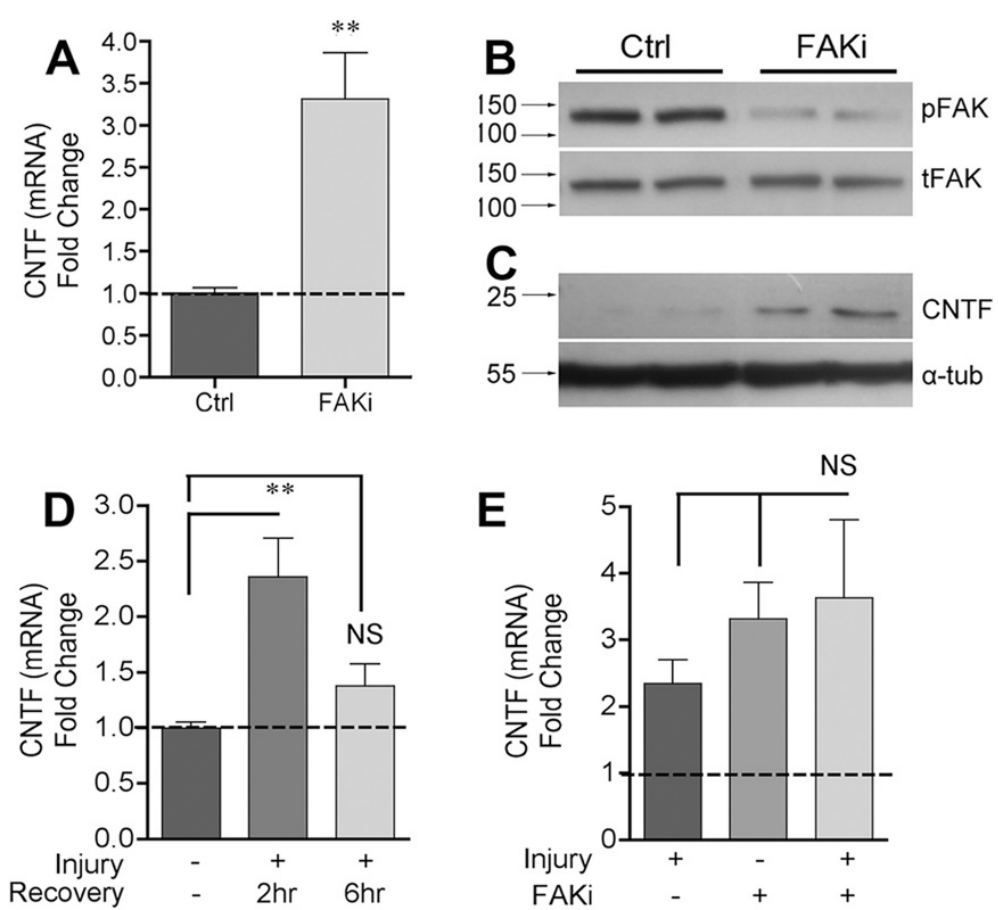

Figure 2 FAK inhibition induces CNTF expression in vitro. A) C6 cells incubated for 4 hours with FAK inhibitor PF573228 have increased levels of CNTF mRNA compared to vehicle-only cultures (Ctrl). B) The inhibitor reduced FAK activity as shown in Western blots by the reduced levels of phosphorylated FAK (pFAK tyr-397). C) CNTF protein was also increased in the same protein extracts, showing the rapid and robust nature of the disinhibition. Blots are representative of 4 independent observations. D) C6 cell injury by mechanical dissociation robustly induced CNTF mRNA within 2 hours which was lost by 6 hours. E) FAK inhibition did not augment the dissociation-induced CNTF mRNA up-regulation. Data are fold change compared to controls and are shown as average +/- SEM. In A, n=6, D and E, $n=4$. 


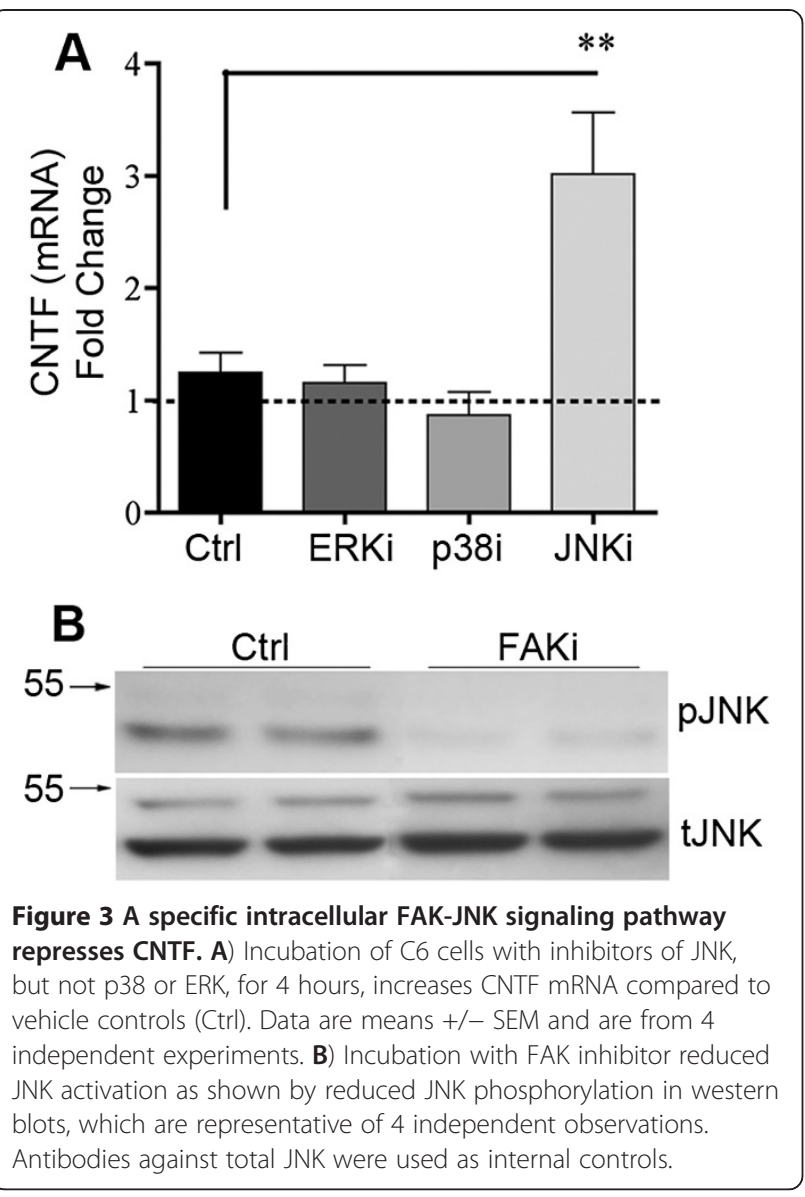

(Ser-727) by JNK [51]. C6 cells treated with FAK inhibitor had decreased STAT3 (Ser-727) phosphorylation (Figure 4A) in the same extracts as the reduction of JNK phosphorylation was shown (Figure 3B). Stattic is a selective inhibitor that blocks STAT3 (Tyr-705) phosphorylation, as well as STAT3 dimerization and translocation to the nucleus [52]. Incubation of stattic 1 hour prior to treatment with FAK inhibitor reduced CNTF mRNA expression 2 fold compared to FAK inhibitor alone suggesting that FA Ki interferes with STAT3-stimulated CNTF expression (Figure 4B). Conversely, co-incubation with an inhibitor of the transcription factor AP-1 failed to affect FAK inhibitor induced CNTF. Our bioinformatics analyses showed that the CNTF promoter ([53]; Rat genome V3.4 Assembly; C6 cells are rat-derived) has a conserved STAT3 binding domain TTTCCTGGGA (Transcription Factor Encyclopedia, [http://www.cisreg.ca]; Motifmap, [http://motifmap.ics.uci. edu]) starting 25 nucleotides upstream of the CNTF initiation point. We also found a consensus sequence at -1954 nucleotides (TTCTGGGAA); [54]. Chromatin immunoprecipitation (ChIP) analyses in C6 cells confirmed that STAT3 binds to genomic DNA containing the CNTF promoter (Figure 4C). DNA sequencing of PCR-amplified product after the pull-down with the STAT3 antibody showed the expected CNTF gene sequence (Figure 4D).

\section{FAK modulates the CNTF-stimulating gp130-STAT3 Tyr-705 pathway}

To determine the functional relevance of a second important STAT3 phosphorylation site (Tyr-705), which is downstream of gp130-containing receptors and can stimulate cytokine expression [55-57] reviewed in [58], we incubated C6 cells with CNTF, IL-6 or LIF. Robust phosphorylation of STAT3 (Tyr-705) was observed as early as 15 minutes (Figure 4E middle row) and at 4 hours by IL- 6 ( $\sim 19$ fold by densitometry; $\mathrm{p}<0.001)$ with lesser induction by CNTF (1.6 fold, $\mathrm{p}<0.05)$ and LIF $(\sim 3$ fold; $\mathrm{p}<0.01)$ relative to vehicle-treated control cells (data not shown). In contrast, phosphorylation of STAT3 (Ser-727) was not affected (Figure 4E, top row). These neural cytokines also did not affect total STAT3 levels (Figure 4E, lower row). Intriguingly, only IL-6 induced CNTF mRNA expression after 4 hours and only by $\sim 10 \%$ (Figure $4 \mathrm{~F} ; \mathrm{p}<0.05$ ). This raised the possibility that the inhibitory FAK pathway largely overrides the CNTF-stimulatory pathway and, therefore, C6 cells were treated with a combination of FAKi with CNTF or IL-6. However, IL-6 and CNTF were unable to further boost FAKi-mediated CNTF induction (Figure 4F). Finally, under the same treatment conditions, FAKi reduced phosphorylation of STAT3 (Tyr-705) most notably in the presence of IL-6 (Figure 4G), suggesting that FAK can activate STAT3 (Tyr-705), in addition to activating the inhibitory STAT3 (Ser-727).

\section{FAKi treatment induces CNTF and neurogenesis in the adult CNS}

The FAK inhibitor PF573228 injected directly into the adult mouse striatum or spinal cord 4 hours later caused a large decrease in pFAK (Figure 5A) and increase in CNTF protein expression (Figure 5B). Control (vehicle only) injected mice contained virtually undetectable levels of CNTF, indicating an essentially complete repression under physiological conditions and a rapid and robust increase after FAK inhibition. Separately, adult mice were injected systemically (i.p.) daily over three days with one of two FAK inhibitors. PF573228 induced CNTF mRNA $\sim 1.8$ and $\sim 1.4$ fold in the spinal cord and SVZ, respectively (Figure 5C). A second FAK inhibitor, FAK14, induced CNTF expression $\sim 1.9$ and 1.4 fold, respectively (Figure 5C).

Endogenous CNTF stimulates normal neuroblast formation from the SVZ [4,5]. SVZ lysates from the mice that were injected systemically over a three day period showed that the proliferative marker Ki67 was upregulated 30\% by each of the FAK inhibitors (Figure 6A). Expression of epidermal growth factor receptor (EGFR), a marker for transient amplifying progenitor SVZ cells [59], was similarly 


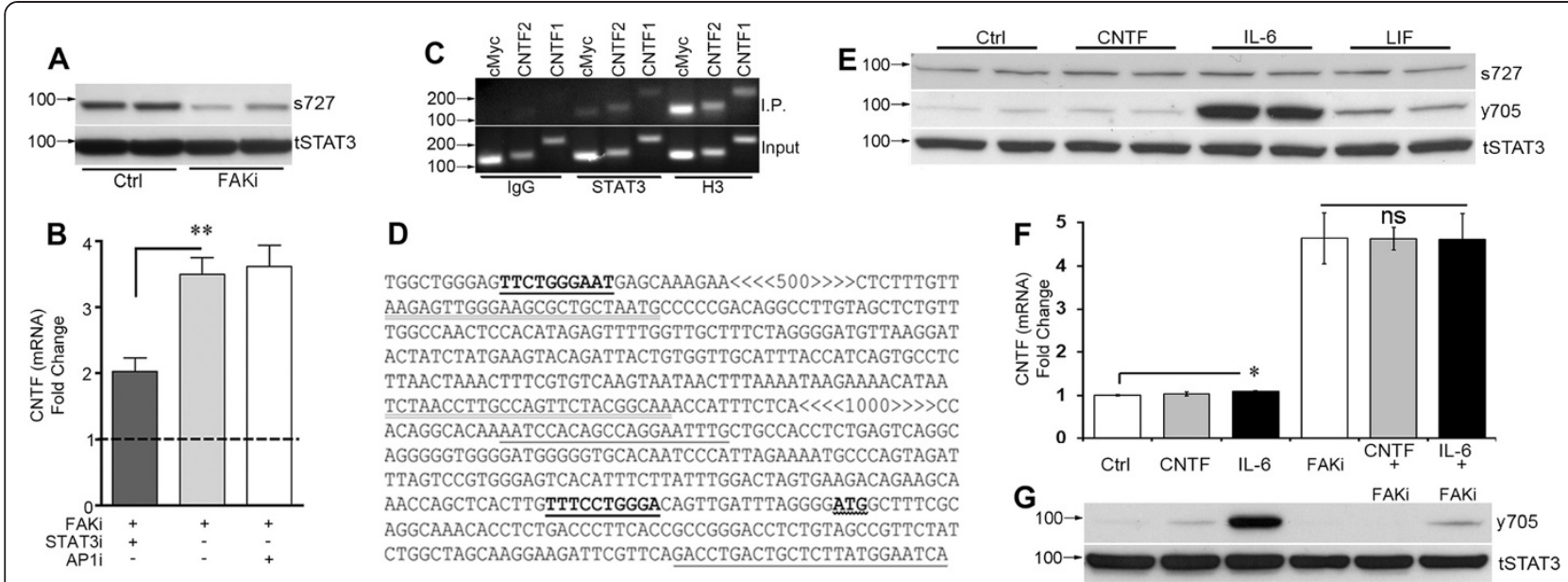

Figure 4 STAT3 inhibition mediates CNTF repression by FAK. A) FAK inhibition reduces STAT3 phosphorylation on its inhibitory residue (s727) as shown in western blots of C6 cells incubated for 4 hours. Total STAT3 antibodies were used as internal controls. B) Pre-incubation with a STAT3 antagonist reduced the CNTF-inducing effects of FAK inhibitor in C6 cells. Thus, FAK represses CNTF by inhibiting STAT3. An AP1 transcription factor antagonist was without effect. Data are fold compared to control (not shown) and means +/-SEM. C) STAT3 binds the CNTF promoter region of C6 cells as shown by ChIP analysis. STAT3 antibody immunoprecipitates (IP) CNTF promoter DNA as shown by the PCR amplification products of two promoter-specific primer sets. Normal rabbit lgG was used as control for non-specific binding. Histone H3 was a positive control. D) Sequencing of the amplification products of the STAT3 immunoprecipitate gave the predicted DNA regions. Key: Consensus STAT3 binding sites; ATG: CNTF initiation site; CNTF1 primer set (FWD, REV); CNTF 2 primer set (FWD, REV); $<>$ denote DNA regions excluded from this panel for presentation purposes. E) IL-6 treatment of C6 cells for 15 minutes robustly increased phosphorylation of STAT3 at the Tyr-705 residue (y705) with modest increases after CNTF and LIF as shown by western blot. Ser-727 phosphorylation (s727) or total STAT3 (tSTAT3) was not affected. Similar results were seen at 4 hours. The blot is representative of 4 independent experiments. F) IL-6 induced only an $\sim 10 \%$ increase in CNTF mRNA expression in C6 cells after 4 hours and did not augment FAKi-induced CNTF expression $(n=3-4$ each, $p<0.05)$. G) FAK inhibition reduced phosphorylation of STAT3 (y705) in C6 cells most notably under IL-6 treated conditions. Antibodies against total STAT3 were used as internal controls for western blots. Results were repeatable in independent experiments.

increased (Figure 6B). In another set of mice, FAK inhibitor PF573228 caused a $56 \%$ increase in the number of SVZ neuroblasts stained for their marker doublecortin (DCX; Figure 6B), confirming that neurogenesis was induced. The SVZ clearly was thicker after systemic FAK inhibitor treatment, representing more DCX cells as shown in confocal images (Figure 6C).

\section{Discussion}

Astrocytes express a number of integrins [60] which are well-known for roles in cell morphology and adhesion [37,61-63], including $\alpha v \beta 5$ integrin. This study identifies an $\alpha v \beta 5$ integrin signaling pathway that regulates gene transcription, inhibiting glial CNTF expression. We cannot rule out that other integrins also repress CNTF as we did not block all integrin subunits, specifically $\alpha v \beta 8$. However, astrocytes respond differently to vitronectin via $\alpha v \beta 5$ and $\alpha v \beta 8$ integrin [61], suggesting that they activate different signaling pathways. Also, adult astrocytes lack $\alpha v \beta 8$ integrin [37]. Our data show selectivity of integrins in regulating CNTF, where blockade of $\alpha v$ and $\beta 5$, but not $\alpha 6$ or $\beta 1$ subunits induced CNTF expression in astroglioma cells. Cell-cell contact enables cultured astrocytes to support oligodendrocyte survival through the $\alpha 6 \beta 1$, but not other integrins [64]. Thus, individual integrins have specific roles for regulating gene expression.

CNTF is a member of a cytokine family, including proinflammatory interleukin-6 (IL-6), that also signal through the gp130 receptor [32,33]. T-cell adhesion induces IL-6 in cultured astrocytes through activation of $\alpha 3 \beta 1$ integrin [65]. Stretch-induced IL-6 expression in endothelial cells is mediated by $\alpha 5 \beta 1$ integrin [66]. Thus, two closely related cytokines are regulated by different integrins and in opposite directions, perhaps representing a mechanism by which astrocytes coordinate responses to pathological conditions. Neuronal BDNF and NGF are also upregulated by RGD-integrin signaling [67], endothelial BDNF by $\beta 1$ integrins [68], and IGF- 1 by $\alpha 2 \beta 1$ and $\alpha 11 \beta 1$ integrins [69]. Thus, compared to other neurotrophic factors, CNTF seems to be unique in being repressed by integrins. This explains its very low level of expression in the brain compared to other neurotrophic factors.

Collectively, our data suggest that the CNTF-repressing integrin signaling pathway contains FAK and JNK which inhibits the transcription factor STAT3 (Figure 7). FAK promotes FGF2-induced migration of astrocytes [70] as expected from focal adhesions [71]. This study extends the role of glial FAK to gene regulation. Neurons also contain FAK [72] and in the adult, it is important for LTP [73] 


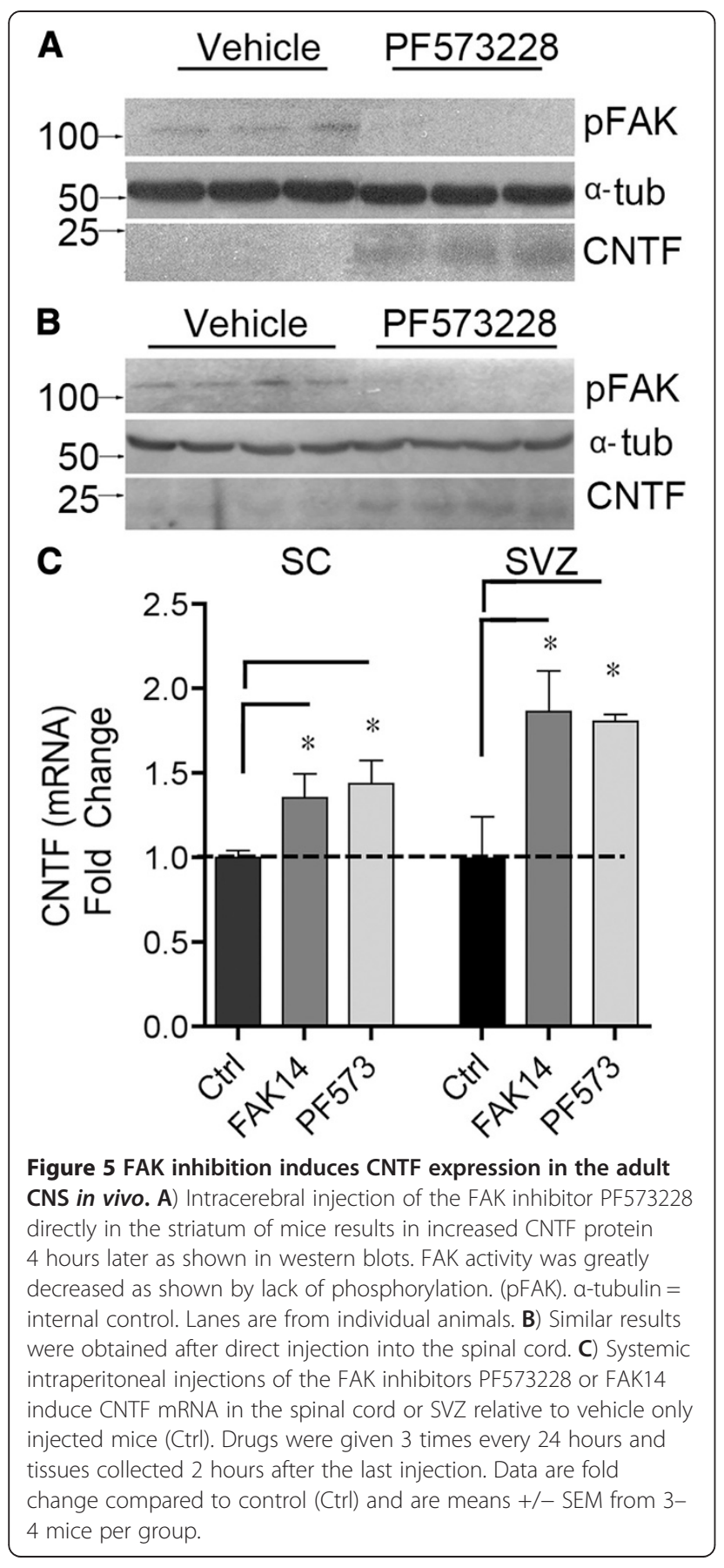

and plasticity [74]. FAK is largely unphosphorylated in the adult brain [75] and activated pFAK immunostaining appears highest in neurons [76]. Thus, astroglial FAK may be more responsive to inhibitors than neurons perhaps explaining why the FAK-treated mice did not have obvious behavioral changes. Clinical trials for cancer with FAK inhibitors which reach the CNS suggest that they are well-tolerated. Even so, it will be important to define the effects of chronic treatment with FAK inhibition on CNS function.
Here, JNK had a selective role in repressing CNTF whereas other major pathways downstream from FAK did not seem to be involved, i.e., ERK and p38 [48,77]. In contrast, FAK-driven JNK and ERK both regulate FGF2induced astroglial migration [70]. The NF-kappaB pathway mediates $\alpha 3 \beta 1$ and $\alpha 5 \beta 1$ integrin stimulation of IL- 6 in astrocytes [65] and endothelial cells [66]. These integrins do not regulate CNTF. Moreover, NF-kappaB is downstream of integrin linked kinase, which associates with $\beta 1$ and $\beta 3$ integrins [78], neither one of which regulates CNTF. Vitronectin activation of $\alpha v \beta 3$ integrin in astrocytes signals through PKC $\alpha$ and RhoA, downstream of FAK [62]. However, these molecules probably do not repress CNTF as $\alpha v \beta 3$ integrin does not either. Therefore, the JNK pathway may specifically repress CNTF, perhaps mediating the effects of vitronectin through $\alpha v \beta 5$ but not $\alpha v \beta 3$ integrin.

The transcription factor Sox10 is a potent positive regulator of CNTF gene transcription in Schwann cells [30]. However, in the CNS, Sox10 is specific to oligodendrocytes [79] and is not induced in reactive astrocytes [80]. It remains to be determined whether other Sox family members regulate CNTF in astrocytes. In cultured astrocytes, the CNTF promoter is also accessible to Peroxisome Proliferator-Activated Receptor gamma (PPAR- $\gamma$ ) in association with cAMP Response Element Binding (CREB) and Activating Transcription Factor 2 (ATF2) [81]. Induction of CNTF by these transcription factors was dependent upon nitric oxide mediated p38 MAPK activity. We propose that the gp130-JAK-STAT3 pathway is an additional pathway activating CNTF transcription in astrocytes, but that the FAK pathway chronically inhibits STAT3 at the Ser-727 residue (Figure 7), providing new insight into co-regulation by integrins and cytokine receptors. FAK inhibition robustly induced CNTF while causing a large reduction in pJNK and pSTAT3 (Ser-727), revealing a novel integrin-STAT3 link. JNK can phosphorylate STAT3 at this inhibitory site [51] and pSTAT3 (Ser-727) can have reduced transcriptional activity $[82,83]$. In apparent contrast, pSTAT3 (Ser-727) can cause stable STAT3STAT3 DNA binding activity [84]. It is possible that pSTAT3 (Ser-727) has gene specific interactions similar to methyl CpG binding protein 2 which can inhibit [85] or activate transcription when associated with other transcription factors [86]. In astrocytes, CNTF induces phosphorylation of STAT3 at Tyr-705 for transcriptional activity in vitro [9,87-90] and in vivo [91]. C6 glioma cells reportedly do not express the CNTF alpha receptor [92] but can respond to CNTF [93], possibly through the IL-6 receptor to activate JAK-STAT3 (Tyr-705) signaling as shown in BaF3 cells [94]. In our hands, CNTF along with LIF only slightly activated STAT3 (Tyr-705) in C6 cells, whereas IL-6 had robust effects. This suggests that the gp130 receptor and not the LIF $\beta R$ required for LIF 

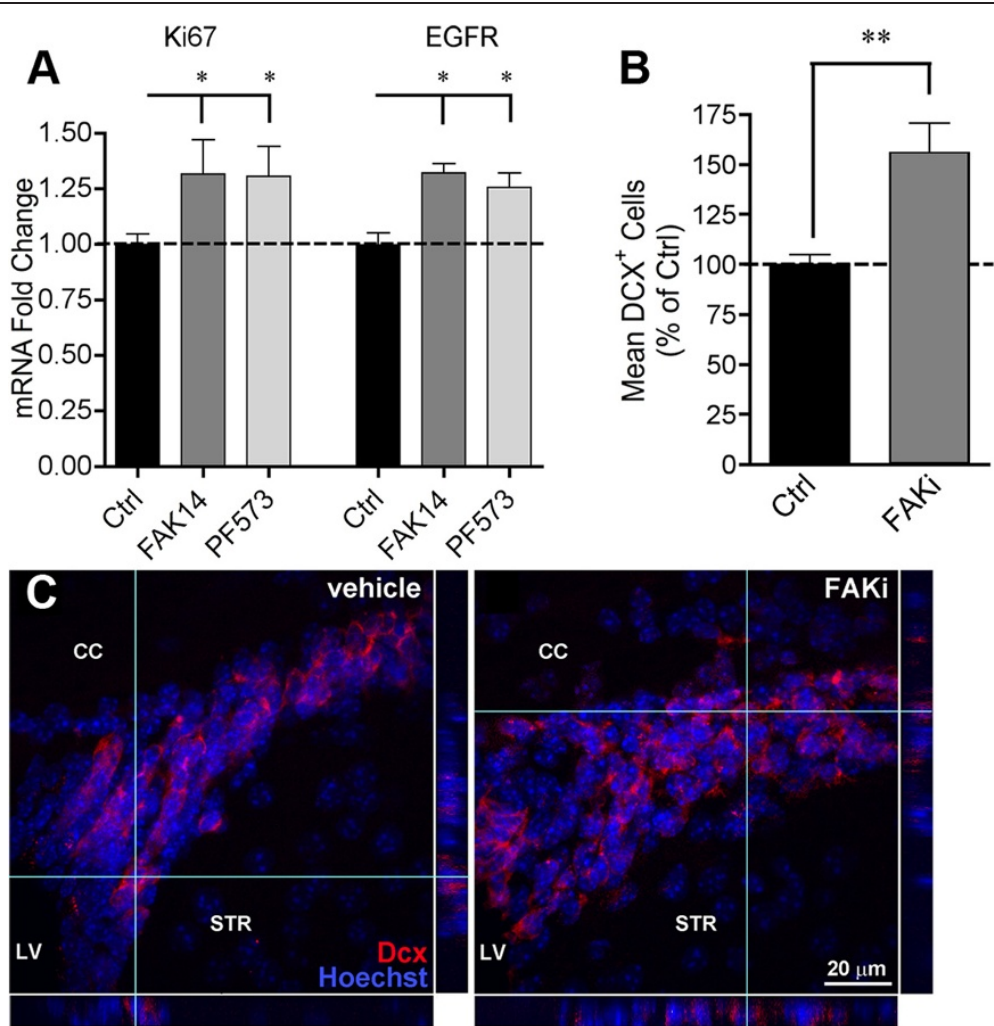

Figure 6 Systemic FAK inhibitor treatment increases adult CNS neurogenesis. A) mRNA for the proliferation marker Ki67 and the marker for proliferating neural C cell progenitors, EGFR, increased in the SVZ after systemic FAK inhibitor PF573228 treatment in mice. CNTF mRNA was increased in the same extracts (Figure 6C). Drugs were given 3 times every 24 hours and tissues collected 2 hours after the last injection. Data are mean fold change compared to vehicle treated mice +/- SEM, $n=3-4$ mice. B) In other mice, the systemic injections of FAK inhibitor PF573228 $(n=6)$ increased the number of DCX + neuroblasts in the SVZ. Data are expressed as a mean percentage of vehicle $(n=4)$ treated mice $+/-$ SEM. C) Representative confocal images of the dorsal SVZ showing increased numbers of nuclei (Hoechst) and neuroblasts (dcx) in an FAK inhibitorinjected mouse compared to a vehicle-injected mouse. Scale bar $=20 \mu \mathrm{m}$. CC = corpus callosum, LV = lateral ventricle, STR = striatum.

binding, is mainly involved in regulating CNTF. The role of STAT3 is also consistent with our finding that IL-6 and CNTF increase CNTF expression in astrocytes of the adult brain [18] and that STAT3 binds the CNTF promoter. This feed-forward autoregulation by CNTF is present in the retina [12] and in astrocyte and C6 astroglioma cell cultures [36].

Despite the robust activation of STAT3 (Tyr-705) by IL6 in C6 cells the increase in CNTF mRNA was only $10 \%$. This suggests that the integrin-mediated inhibitor signaling "brake" is the strongest factor in determining levels of CNTF expression. In fact, IL-6 could not further increase FAKi-induced CNTF expression despite the presence of increased STAT3 (Tyr-705) compared to FAKi alone. Interestingly, FAKi reduced STAT3 (Tyr-705) phosphorylation. Identification of the intermediary signaling molecules that link FAK to STAT3 (Tyr-705) will require further study. This dual integrin-related mechanism to regulate CNTF indicates that CNTF is a highly regulated gene which is only modulated slightly under normal physiological conditions. Under pathological conditions
CNTF may be greatly induced by the loss of cell-cell contact, immediately releasing the inhibitory STAT3 pathway independent of expression of cytokines, perhaps helping to make this a rapid first-responder system. The complete loss of contact, however, and therefore FAK stimulation of STAT3 (Tyr-705) might reduce the potency of other growth factors that signal through the STAT3 pathway.

Interestingly, STAT3 independently from its transcriptional function is necessary to maintain normal mitochondrial bioenergetic function, which is dependent on Ser-727 whose phosphorylated form is highly enriched in mitochondria [95,96]; reviewed in [97]. This mechanism is also present in cortical astrocytes [98]. In light of our findings, it is possible that integrin ligand binding promotes mitochondrial function through FAK-JNK-mediated STAT3 (Ser-727) phosphorylation. Whether and how the mitochondrial effects of STAT3 might affect CNTF expression remains to be determined. CNTF has also recently been found to normalize mitochondrial function in diabetic conditions [99]. This raises the possibility that under pathological conditions that reduce Ser-727 activity, 


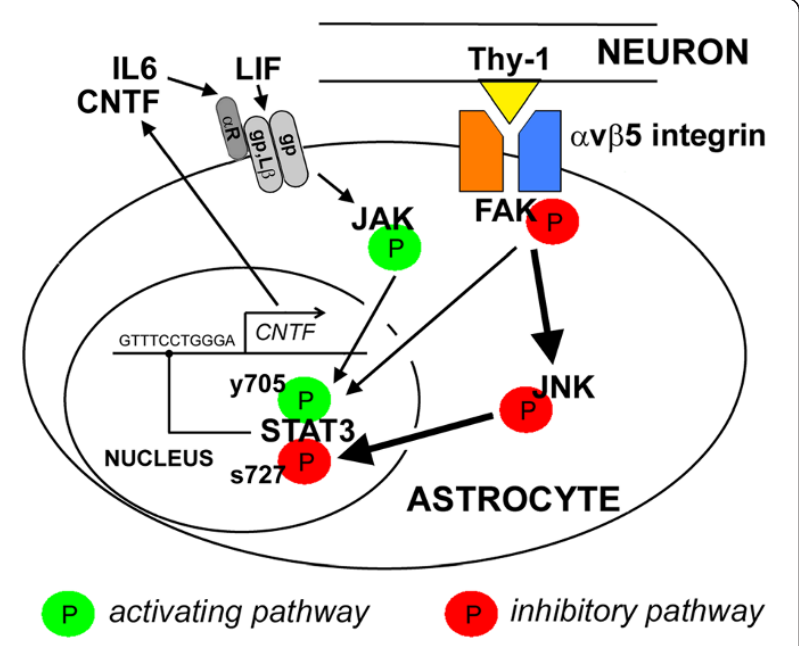

Figure 7 Schematic representation of the proposed pathways that regulate astroglial CNTF. This study identifies an inhibitory pathway (Red) where ligands such neuronal Thy-1 bind to astrocyte avß5 integrin resulting in FAK phosphorylation. Subsequently, JNK is activated and phosphorylates STAT3 at an inhibitory serine-727 (s727) residue potently repressing transcription of CNTF. Conversely, the CNTF-stimulatory pathway is activated by neural cytokines such as CNTF, LIF and IL-6 which bind to their respective gp130 (gp) receptor complexes (CNTF: CNTFaR/LIFßR/gp130; LIF: LIFßR/gp130; IL-6: IL-6aR/gp130/gp130; L $\beta$ indicates LIF $\beta R$ ), triggering recruitment of JAK to activate STAT3 by phosphorylation at the pro-transcription residue tyrosine-705, y705; Green). CNTF is known to activate STAT3 in astrocytes in vitro [9,87-90] and in vivo [91]. FAK may simultaneously stimulate the activating pathway, potentially representing another component of the tightly regulated CNTF gene expression under physiological conditions.

CNTF expression is disinhibited in part to maintain mitochondrial function.

The function of CNTF continues to be elucidated with evidence of its role extending to stimulation of mitochondrial bioenergetic function via NF-kB signaling [99] as well as regulating neurogenesis [18] and neuroprotection [19]. With such diverse functions and as a mediator of critical protective STAT3 signaling in neurons [90], it is likely that several molecular mechanisms exist that lead to CNTF transcription.

The role of neural Thy- 1 is poorly understood despite being highly enriched in the brain and exclusively present on neurons [100]. We identify Thy- 1 as one of the neuronal ligands that mediates contact-dependent repression of CNTF in astrocytes. This is consistent with the finding that Thy- 1 increases 100 fold during early post natal development in the CNS [24] when CNTF expression stays low, whereas it increases greatly in the peripheral nervous system during a similar time frame [15]. Thy-1 binds to astrocytic $\alpha v \beta 3$ integrin to activate FAK resulting in morphological changes and cell-cell attachment $[62,71]$. Thy-1 can bind directly to $\alpha v \beta 5$ integrin in lung fibroblasts [26], consistent with our findings that $\alpha v \beta 5$ integrin represses
CNTF and Thy-1 inhibition increases CNTF. Neuronal loss in the adult mouse brain induces CNTF within hours [18] possibly by disinhibition of Thy-1. It remains to be determined whether the other integrin substrates which inhibited CNTF expression in vitro play a similar role in the CNS. Laminin is produced by astrocytes [101] and neurons [6], vitronectin by endothelial cells [42] and fibronectin is associated with astrocytes [43].

FAK plays key roles during nervous system development [75] but its role and that of downstream JNK in adult neurogenesis had not been investigated. Importantly, inhibition of FAK with systemic drugs rapidly induced CNTF protein expression which was biologically active as suggested by the increased formation of new neuroblasts in the adult mouse SVZ. This is consistent with our findings that endogenous CNTF enhances proliferation of progenitors in the SVZ without affecting normal neuronal cell fate choice $[4,5]$. Our data are also consistent with the finding that SVZ neurogenesis is dependent on STAT3 [102]. Our finding that CNTF expression is higher in the SVZ than most other brain regions [5] is consistent with the absence of neuronal Thy- 1 in the SVZ and RMS (Allen Brain Atlas, [www.brain-map.org]). This may allow CNTF-induced proliferation until the neuroblasts reach their target in the olfactory bulb which is rich in Thy-1. Integrins such as $\alpha 6 \beta 1, \alpha v$ and $\beta 8$, and ligands such as laminin, play a key role in neuroblast migration [103-108]. Little is known about gene regulation by integrins in the SVZ. Interestingly, $\alpha 6$ blocking antibodies increased SVZ proliferation in vivo [106], suggesting that there is an additional growth factor which is repressed by laminin.

\section{Conclusion}

Our data suggest that FAK inhibition rapidly induces CNTF protein expression from very low levels within four hours in vivo. This is consistent with our finding that CNTF mRNA doubles within one hour after stroke to serve a neuroprotective role [18]. Consistent with the current data, blockade of integrins with RGD peptides reduced pFAK and decreased infarct area in a rodent model of stroke [76]. We propose that this integrin-FAK pathway constitutes a sensitive neuroglial sensor for regulating neurotrophic support or neuronal function in the CNS. This study also opens up avenues for pharmacologically stimulating and utilizing the neuroprotective actions of endogenous CNTF in neurological diseases, thus circumventing the low CNS bioavailability and systemic side effects of systemic administered CNTF [14].

\section{Methods}

All procedures involving animals were carried out in accordance with $\mathrm{NIH}$ guidelines and approved by the University of Louisville Institutional Animal Care and Use Committee (IACUC). Data are shown as average \pm SEM. 


\section{Cell culture}

C6 astroglioma cells were obtained from ATCC and were maintained in in t75 culture flasks (USA Scientific) in DMEM supplemented with $10 \%$ Fetal Calf Serum, $1 \mathrm{mM}$ L-Glutamine, $100 \mathrm{U}$ Penicillin and $100 \mu \mathrm{g}$ Streptomycin (All Gibco). Cells were passaged every three days after washing with PBS and incubation with $0.05 \%$ trypsin: Hanks Balanced Salt Solution for 2 minutes. After centrifugation, cell pellets were resuspended in fresh medium, plated at $160,000 \mathrm{ml}^{-1}$ and maintained for 24 hours except where noted. C6 cells were only used between passage number 10-40.

To test effects of ECM ligands C6 cells were cultured for 4 hours on poly-d-lysine $(50 \mu \mathrm{g} / \mathrm{ml}$; Sigma, USA) coated multi-well culture plates ( 6 well, Corning) coated with vitronectin $(50 \mu \mathrm{g} / \mathrm{ml}$, \#SRP3186), laminin $(50 \mu \mathrm{g} / \mathrm{ml}$, \#L2020), fibronectin (50 $\mu \mathrm{g} / \mathrm{ml}$, \#F3667), thrombospondin $\left(0.25 \mu \mathrm{g} / \mathrm{cm}^{2}\right.$, \#SRP4805), fibrinogen (50 $\mu \mathrm{g} / \mathrm{ml} \mathrm{\# F3879)} \mathrm{or}$ collagen type I (100 $\mu \mathrm{g} / \mathrm{ml}$, \#C5533, all Sigma) before isolation of RNA. For antibody experiments, freshly plated C6 cells were incubated with neutralizing antibodies against $\alpha \mathrm{v}(5 \mu \mathrm{g} / \mathrm{ml}$, \#104108, Biolegend, UK; [109,110]), $\alpha 6$ (5 $\mu \mathrm{g} /$ $\mathrm{ml}$ \#313614, Biolegend; [111]), $\beta 1$ (5 $\mu \mathrm{g} / \mathrm{ml}$, \#102210, Biolegend; [112]) or $\beta 5(5 \mu \mathrm{g} / \mathrm{ml}$, \#12-0497-41, eBiosciences, USA; $[113,114])$ integrins or IgG control $(5 \mu \mathrm{g} /$ $\mathrm{ml}$, \#402014, Biolegend) for 4 hours before isolating RNA. Pharmacological antagonists against JNK (SP600125; $25 \mu \mathrm{M}$; Sigma; [115]), p38 (SB203580;10 $\mu \mathrm{M}$; Tocris; [116]), ERK (SL327, $50 \mu \mathrm{M}$; Tocris; [117]) or FAK (PF573228; $10 \mu \mathrm{M}$; Tocris; [118]) were incubated with C6 cells for 4 hours, 24 hours after initial plating. To block STAT3 activation, the selective small molecule inhibitor Stattic $(10 \mu \mathrm{M}$; Tocris; [52]) was incubated with C6 cells 1 hour before addition of FAKi (PF573228). To block AP-1 activity $\mathrm{C} 6$ cells were incubated with the AP-1 antagonist SR11302 (10 $\mu \mathrm{M}$; Tocris; $[119,120]) 1$ hour prior to coincubation with FAKi (PF573228). We did not include negative controls for these inhibitors because most of the drugs used in this study are relatively well studied and elucidated and also, we do not know of the existence of inactive enantiomers for PF573228. The drugs which lacked effects on CNTF expression may serve as negative controls for the ones that did have an effect.

Primary astrocyte-neuron co-cultures were performed as described before from the cortices of neonatal C57BL/6 mice [18]. Neurons $\left(0.5 \times 10^{6} / \mathrm{ml}\right)$ were incubated with Thy- 1 neutralizing antibodies $(5 \mu \mathrm{g} / \mathrm{ml}$; \#105309, Biolegend; [121]) or isotype IgG control (5 $\mu \mathrm{g} / \mathrm{ml}$; \#402014, Biolegend) before seeding onto the astrocytes or poly-D- lysine-coated plates. RNA was isolated after 24 hours.

\section{In vivo injections}

Stereotaxic injection into the striatum of anesthetized mice was performed as described [18] through a glass needle with a $35 \mu \mathrm{m}$ diameter tip attached to a pico spritzer (Parker Instrumentation) and loaded with either vehicle (75\% DMSO in saline) or $20 \mu \mathrm{g}$ PF573228 (Cat\#3239, Tocris) in vehicle. One day later, the mice were transcardially perfused with ice cold PBS, the striatum dissected and flash frozen at $-80^{\circ} \mathrm{C}$. To inject in the spinal cord, the vertebral column was stabilized in a frame, the cord exposed with a laminectomy at thoracic level 9 and the dura incised. A volume of $1 \mu \mathrm{l}$ containing vehicle or $20 \mu \mathrm{g}$ PF573228 was injected into the middle of the cord. After 4 hours, mice were transcardially perfused, and a $3 \mathrm{~mm}$ section of cord with the injection site in the middle was dissected and flash frozen.

Systemic i.p. injections of FAK inhibitors were applied daily over three days with $30 \mathrm{mg} / \mathrm{kg} /$ day PF573228 dissolved in $100 \mu \mathrm{l}$ of $75 \%$ DMSO or $30 \mathrm{mg} / \mathrm{kg} /$ day FAK14 (Cat\#3414; Tocris), dissolved in $100 \mu \mathrm{l}$ PBS. The brains of these mice were collected 2 hours after the last injection and processed for measuring CNTF mRNA levels. Other mice were processed for histology as described further on.

\section{Quantitative-RT-PCR}

Total RNA was extracted from tissue and cells with the miRVana RNA isolation kit (Ambion) according to manufacturer's protocol. RNA concentration was measured with a nano-drop Spectrophotometer. Quantitative Real Time RT-PCR (qPCR) was performed as described [18] with some minor alterations. Briefly, $0.5 \mu \mathrm{g}$ of RNA was treated with DNAse to destroy contaminating DNA according to standard procedure. DNAse was inactivated before RNA was used to generate cDNA. Complimentary DNA was generated from $0.5 \mu \mathrm{g}$ of RNA using MMLV reverse transcriptase (200 U), $0.5 \mu \mathrm{g}$ random hexamers, $0.5 \mathrm{mM}$ dNTP mix in a $25 \mu \mathrm{l}$ reaction. Reactions were incubated for one hour at $37^{\circ} \mathrm{C}$. The cDNA was then used with Applied Biosytems qRT-PCR primer sets specific to mouse CNTF (mM00446373_m1), GAPDH (mM4352339E), EGFR (mM00433023) and Ki67 (mM01278606) and rat primer sets were CNTF (Rn00755092) and GAPDH (Rn99999916; all Applied Biosystems). PCR reactions were performed using the TaqMan Gene Expression Master Mix (4369016, Applied Biosystems) with the following cycling parameters: 10 minutes at $95^{\circ} \mathrm{C}$ followed by 40 cycles of; $95^{\circ} \mathrm{C}$ for $15 \mathrm{sec} ; 60^{\circ}$ for 1 minute in an ABI 7900 Thermal Cycler (Applied Biosystems). Data analysis was performed with the $\Delta \Delta \mathrm{Ct}$ method with GAPDH serving as an endogenous control.

\section{ChIP analysis}

ChIP analysis was performed with the Millipore ChIP kit (\#17-294, Millipore, USA) according to the manufacturer's protocol with some minor modifications. A total of 2.56 million C6 cells were plated at 160,000 cells $/ \mathrm{ml}$ in $75 \mathrm{~cm}^{2}$ flasks for 24 hours, then treated with vehicle (75\% DMSO) 
or $10 \mu \mathrm{M}$ FAK inhibitor PF573228 in vehicle (Cat. \#3239, Tocris) for 4 hours. C6 cells were fixed with $1 \%$ formaldehyde for 10 minutes at room temperature and then washed with and resuspended in ice cold PBS supplemented with a protease inhibitor cocktail (Cat\# P8340, Sigma). Cells were scraped and centrifuged at $4^{\circ} \mathrm{C}$ for 5 minutes at 2,000 rpm, after which the cell pellet was resuspended in 1x SDS lysis buffer and left on ice for 10 minutes. Chromatin was sheared by sonication (Misonix, XL-2000) on ice (six pulses of 10 seconds at a setting of 3) to an average size of sheared chromatin of $500 \mathrm{bp}$ and up to $\sim 1.5-2 \mathrm{Kbp}$. Sonicated samples were centrifuged for 10 minutes at $14,000 \mathrm{rpm}$ at $4^{\circ} \mathrm{C}$ to remove any debris, and the supernatant was divided into $200 \mu \mathrm{l} \mathrm{al}-$ iquots containing material from 1 million cells for each ChIP analysis, and then snap frozen and stored at $-80^{\circ} \mathrm{C}$. ChIP grade rabbit polyconal antibodies were against STAT3 (\#9132, Cell Signaling, USA) or for normalization, Histone H3 (ab1791, Abcam, UK). Normal rabbit IgG (Cat\#2729, Cell Signaling) was used as a control for nonspecific binding. Immunoprecipitation was performed according to manufacturer's protocol. Chromatin precipitated DNA was resuspended in a final volume of $40 \mathrm{ul}$ of water (both for IP samples and input samples) and 1/10th of each was used for the PCR amplification. Primers were (Forward; Reverse): CNTF primer set 1 starting at $25 \mathrm{bp}$ upstream from the CNTF initiation site (P3), 5'AATCCACAGCCAGGAATTTG-3' and 5'-GATTCCAT AAGAGCAGTCAGGTC-3', and CNTF primer set 2 starting at 1425 bp (P6), 5'-AAGAGTTGGGAAGC GCTGCTAATG-3' and 5'-TGCCGTAGAACTGGCAA GGTTAGA-3'; cMyc; a known target of STAT3 mediated transcription [122] and in C6 glioma cells [123] was $5^{\prime}$ GTCAACATAGCTGTACGCCCAAACGC-3', and 5'-G TTATGTAGGAGCCCTTGCTCAGTGTG-3'. Reactions were prepared in a final volume of $20 \mu \mathrm{l}$ with $1 \mathrm{x}$ PCR buffer, $200 \mu \mathrm{M}$ dNTP, $1.5 \mathrm{mM} \mathrm{MgCl}{ }^{2}, 0.5 \mu \mathrm{M}$ each forward and reverse primers, $1 / 10$ chromatin immunoprecipitated (or Input) DNA sample and 0.5 U of Taq DNA polymerase. The PCR cycle used were 3 minutes at $94^{\circ} \mathrm{C}$ for the initial denaturation, 36 cycles of 45 seconds of $94^{\circ} \mathrm{C}$, 30 seconds at $60^{\circ} \mathrm{C}, 60$ seconds at $72^{\circ} \mathrm{C}$, followed by 10 minutes at $72^{\circ} \mathrm{C}$. ChIP amplification products were sequenced at the University of Louisville DNA Core Facility.

\section{Western blotting}

Protein lysate from cell cultures was isolated using RIPA buffer $(50 \mathrm{mM}$ Tris-HCl, 1\% [w/v] Tergitol, 0.25\% [w/v] Sodium deoxycholate, $150 \mathrm{mM} \mathrm{NaCl}$ and $100 \mathrm{mM}$ EDTA) supplemented with $1 \mathrm{mM}$ sodium orthovanadate, $5 \mathrm{mM}$ sodium fluoride and $0.1 \%[\mathrm{v} / \mathrm{v}]$ protease inhibitor cocktail. Cells were washed in ice cold PBS (Gibco) before cells were scraped from the surface with an inverted p1000 pipette tip in RIPA buffer. Lysate was transferred to
Eppendorf tubes and placed on ice. The lysate was then triturated using a $1 \mathrm{ml}$ syringe (BD) and $26^{1 / 2}$ gauge needle before samples were returned to ice and incubated for 30 minutes. Samples were centrifuged at $12,300 \mathrm{rpm}$ at $4^{\circ} \mathrm{C}$ for 15 minutes. Lysate was then transferred to fresh Eppendorf tubes and stored at $-80^{\circ} \mathrm{C}$ or prepared for protein quantitation with Pierce's BCA protein assay as per manufacturer's instructions. Proteins were separated by SDS-PAGE and blotting was then performed with specific antibodies for CNTF (1:400; MAB338, Millipore), or with FAK (1:1000; Cat\#3285), pFAK-Tyr397 (1:1000; Cat\#3283), JNK (1:1000; Cat\#3708), pJNK-Tyr185 (1:1000; Cat\#9251), pSTAT3-Ser727 (1:500; Cat\#9134), pSTAT3Tyr705 (1:1000; Cat \#9145). Concentration used was 1/1000 STAT3 (1:1000; Cat\#9132), $\alpha$ Tubulin (1:2000; Cat\#2125), all from Cell Signaling Technology. Briefly, after transfer, PVDF membranes were blocked in 5\% nonfat milk in Tris buffered saline with $0.05 \%$ tween (TBST) for 1 hour then incubated overnight $\left(4^{\circ} \mathrm{C}\right)$ in primary antibody (5\% milk:TBST). Blots were washed with TBST before incubation (2 hours; room temperature) with appropriate Horse Radish Peroxidase conjugated secondary antibodies (anti-mouse, Cat\#7076 and anti-rabbit, Cat\#7074, Cell Signaling) in 5\% milk; TBST. Blots were washed and ECL substrate used to visualize antibodies according to standard procedures.

\section{Immunocytochemistry}

Mice were transcardially perfused with ice-cold PBS followed by $4 \%$ paraformaldehyde. Their brains were extracted, post-fixed overnight and cryoprotected in 30\% sucrose in PB for 24 hours. Coronal $30 \mu \mathrm{m}$ thick sections were cut on a sliding freezing microtome. Starting at a random point along the rostrocaudal axis of the brain, every sixth section through the SVZ was immunostained for doublecortin (dcx) to detect neuroblasts. Briefly, sections were incubated in $5 \%$ donkey for 1 hour followed by overnight incubation $\left(4^{\circ} \mathrm{C}\right)$ with goat anti-DCX (1:500, SC8066, Santa Cruz). Secondary antibodies were anti-goat IgG (1:500, Alexa Fluor 488, A11055, Invitrogen) for 1 hour at room temperature. Sections were incubated with Hoechst $(1 \mu \mathrm{g} / \mathrm{ml})$ before cover slipping for imaging. Confocal images were taken on a Nikon D-Eclipse C1 confocal microscope. The images of $1024 \times 1024 x-y$ pixel and $8.4 \mu \mathrm{m} z$-stack were taken using a 100x oil objective.

\section{Cell counting and statistical analysis}

The number of neuroblasts was counted independently by two investigators blinded to the treatment using a 20x objective (Leica DM6000 microscope) by identifying dcx-positive cells with Hoechst-labeled nuclei in the most populated dorsal quadrant of the SVZ. Cells were 
counted at the same area $(35 \mu \mathrm{m} \times 15 \mu \mathrm{m}$ rectangular box) overlaying the entire width of the SVZ using 4 sections per brain. Statistical analyses were performed with Student's $t$ test or One Way Analysis of Variance (ANOVA) with a Dunnett's or Bonferroni post-hoc test where noted. A value of $p<0.05$ considered as statistically significant.

\section{Abbreviations}

CNTF: Ciliary Neurotrophic factor; JNK: c-Jun N-terminal kinase; FAK: Focal Adhesion Kinase; ERK: Extracellular regulated kinase; MAPK: Mitogen Activated Protein Kinase; SVZ: Subventricular Zone; EAE: Experimental autoimmune encephalomyelitis; ECM: Extracellular matrix; pFAK: Phosphorylated FAK; FAKi: FAK antagonist; pJNK: Phosphorylated JNK; STAT3: Signal Transducer and Activator of Transcription 3; EGFR: Epidermal growth factor receptor; IL-6: Interleukin-6; pSTAT3: Phosphorylated STAT3; PPAR-y: Peroxisome Proliferator-Activated Receptor gamma; CREB: Cyclic AMP Response Element Binding; ATF2: Activating Transcription Factor 2.

\section{Competing interests}

The authors have no financial or non-financial conflicts of interest.

\section{Authors' contributions}

MPK, SSK, CL and TH designed and performed experiments, analyzed data and wrote the manuscript. All authors read and approved the final manuscript.

\section{Acknowledgements}

We wish to thank Hillary Conway, Johongir Muradov and Sheila Arnold for technical assistance, Dr. Douglas Dean for advice on ChIP analyses. This work was supported by NIH grants AG29493 and GM103507, Norton Healthcare, and the Commonwealth of Kentucky Challenge for Excellence.

Received: 7 February 2013 Accepted: 13 May 2013

Published: 21 May 2013

\section{References}

1. Barres BA, Burne JF, Holtmann B, Thoenen H, Sendtner M, Raff MC: Ciliary neurotrophic factor enhances the rate of oligodendrocyte generation. Mol Cell Neurosci 1996, 8:146-156.

2. Zurn AD, Werren F: Development of CNS cholinergic neurons in vitro: selective effects of CNTF and LIF on neurons from mesencephalic cranial motor nuclei. Dev Biol 1994, 163:309-315.

3. Stoop R, Poo MM: Potentiation of transmitter release by ciliary neurotrophic factor requires somatic signaling. Science 1995, 267:695-699.

4. Emsley JG, Hagg T: Endogenous and exogenous ciliary neurotrophic factor enhances forebrain neurogenesis in adult mice. Exp Neurol 2003, 183:298-310.

5. Yang P, Arnold SA, Habas A, Hetman M, Hagg T: Ciliary neurotrophic factor mediates dopamine D2 receptor-induced CNS neurogenesis in adult mice. J Neurosci 2008, 28:2231-2241.

6. Hagg T, Quon D, Higaki J, Varon S: Ciliary neurotrophic factor prevents neuronal degeneration and promotes low affinity NGF receptor expression in the adult rat CNS. Neuron 1992, 8:145-158.

7. Kumon Y, Sakaki S, Watanabe H, Nakano K, Ohta S, Matsuda S, Yoshimura H, Sakanaka M: Ciliary neurotrophic factor attenuates spatial cognition impairment, cortical infarction and thalamic degeneration in spontaneously hypertensive rats with focal cerebral ischemia. Neurosci Lett 1996, 206:141-144

8. Emerich DF, Winn SR, Hantraye PM, Peschanski M, Chen EY, Chu Y, McDermott P, Baetge EE, Kordower JH: Protective effect of encapsulated cells producing neurotrophic factor CNTF in a monkey model of Huntington's disease. Nature 1997, 386:395-399.

9. Garcia P, Youssef I, Utvik JK, Florent-Béchard S, Barthélémy V, MalaplateArmand C, Kriem B, Stenger C, Koziel V, Olivier J-L, Escanye M-C, Hanse M, Allouche A, Desbène C, Yen FT, Bjerkvig R, Oster T, Niclou SP, Pillot T: Ciliary neurotrophic factor cell-based delivery prevents synaptic impairment and improves memory in mouse models of Alzheimer's disease. J Neurosci 2010, 30:7516-7527.

10. Simon CM, Jablonka S, Ruiz R, Tabares L, Sendtner M: Ciliary neurotrophic factor-induced sprouting preserves motor function in a mouse model of mild spinal muscular atrophy. Hum Mol Genet 2010, 19:973-986.

11. Cui Q, Yip HK, Zhao RCH, So K-F, Harvey AR: Intraocular elevation of cyclic AMP potentiates ciliary neurotrophic factor-induced regeneration of adult rat retinal ganglion cell axons. Mol Cell Neurosci 2003, 22:49-61.

12. Müller A, Hauk TG, Leibinger M, Marienfeld R, Fischer D: Exogenous CNTF stimulates axon regeneration of retinal ganglion cells partially via endogenous CNTF. Mol Cell Neurosci 2009, 41:233-246.

13. Cao Q, He Q, Wang Y, Cheng X, Howard RM, Zhang Y, DeVries WH, Shields CB, Magnuson DSK, Xu X-M, Kim DH, Whittemore SR: Transplantation of ciliary neurotrophic factor-expressing adult oligodendrocyte precursor cells promotes remyelination and functional recovery after spinal cord injury. J Neurosci 2010, 30:2989-3001.

14. Thoenen $\mathrm{H}$, Sendtner M: Neurotrophins: from enthusiastic expectations through sobering experiences to rational therapeutic approaches. Nat Neurosci 2002, 5(Suppl):1046-1050.

15. Stöckli KA, Lottspeich F, Sendtner M, Masiakowski P, Carroll P, Götz R, Lindholm D, Thoenen $\mathrm{H}$ : Molecular cloning, expression and regional distribution of rat ciliary neurotrophic factor. Nature 1989, 342:920-923.

16. Asada H, Ip NY, Pan L, Razack N, Parfitt MM, Plunkett RJ: Time course of ciliary neurotrophic factor mRNA expression is coincident with the presence of protoplasmic astrocytes in traumatized rat striatum. J Neurosci Res 1995, 40:22-30.

17. Park CK, Ju WK, Hofmann HD, Kirsch M, Ki Kang J, Chun MH, Lee MY: Differential regulation of ciliary neurotrophic factor and its receptor in the rat hippocampus following transient global ischemia. Brain Res 2000, 861:345-353.

18. Kang SS, Keasey MP, Arnold SA, Reid R, Geralds J, Hagg T: Endogenous CNTF mediates stroke-induced adult CNS neurogenesis in mice. Neurobiol Dis 2012, 49C:68-78.

19. Linker RA, Mäurer M, Gaupp S, Martini R, Holtmann B, Giess R, Rieckmann P, Lassmann H, Toyka KV, Sendtner M, Gold R: CNTF is a major protective factor in demyelinating CNS disease: a neurotrophic cytokine as modulator in neuroinflammation. Nat Med 2002, 8:620-624.

20. Müller GJ, Lassmann H, Johansen FF: Anti-apoptotic signaling and failure of apoptosis in the ischemic rat hippocampus. Neurobiol Dis 2007, 25:582-593.

21. Barczyk M, Carracedo S, Gullberg D: Integrins. Cell Tissue Res 2010, 339:269-280

22. Hagg T, Muir D, Engvall E, Varon S, Manthorpe M: Laminin-like antigen in rat CNS neurons: distribution and changes upon brain injury and nerve growth factor treatment. Neuron 1989, 3:721-732.

23. Yin $Y$, Kikkawa $Y$, Mudd JL, Skarnes WC, Sanes JR, Miner JH: Expression of laminin chains by central neurons: analysis with gene and protein trapping techniques. Genesis 2003, 36:114-127.

24. Morris R: Thy-1 in developing nervous tissue. Dev Neurosci 1985, 7:133-160.

25. Hermosilla T, Muñoz D, Herrera-Molina R, Valdivia A, Muñoz N, Nham S-U, Schneider P, Burridge K, Quest AFG, Leyton L: Direct Thy-1/alphaVbeta3 integrin interaction mediates neuron to astrocyte communication. Biochim Biophys Acta 2008, 1783:1111-1120.

26. Zhou Y, Hagood JS, Lu B, Merryman WD, Murphy-Ullrich JE: Thy-1-integrin alphav beta5 interactions inhibit lung fibroblast contraction-induced latent transforming growth factor-beta1 activation and myofibroblast differentiation. J Biol Chem 2010, 285:22382-22393.

27. Bello L, Francolini M, Marthyn P, Zhang J, Carroll RS, Nikas DC, Strasser JF, Villani R, Cheresh DA, Black PM: Alpha(v)beta3 and alpha(v)beta5 integrin expression in glioma periphery. Neurosurgery 2001, 49:380-389. discussion 390.

28. Herrera-Molina R, Frischknecht $\mathrm{R}$, Maldonado $\mathrm{H}$, Seidenbecher $\mathrm{Cl}$, Gundelfinger ED, Hetz C, Aylwin M de LL, Schneider P, Quest AFG, Leyton L: Astrocytic aV $\beta 3$ integrin inhibits neurite outgrowth and promotes retraction of neuronal processes by clustering Thy-1. PLoS One 2012, 7:e34295.

29. Giancotti FG, Ruoslahti E: Integrin signaling. Science 1999, 285:1028-1032

30. Ito Y, Wiese S, Funk N, Chittka A, Rossoll W, Bömmel H, Watabe K, Wegner $M$, Sendtner M: Sox10 regulates ciliary neurotrophic factor gene expression in Schwann cells. Proc Natl Acad Sci USA 2006, 103:7871-7876.

31. Stolt CC, Rehberg S, Ader M, Lommes P, Riethmacher D, Schachner M, Bartsch $U$, Wegner M: Terminal differentiation of myelin-forming oligodendrocytes depends on the transcription factor Sox10. Genes Dev 2002, 16:165-170. 
32. Boulton TG, Zhong Z, Wen Z, J E Darnell J, Stahl N, Yancopoulos GD: STAT3 activation by cytokines utilizing gp130 and related transducers involves a secondary modification requiring an $\mathrm{H} 7$-sensitive kinase. Proc Natl Acad Sci USA 1995, 92:6915.

33. Zigmond RE: gp130 cytokines are positive signals triggering changes in gene expression and axon outgrowth in peripheral neurons following injury. Front Mol Neurosci 2011, 4:62.

34. Humphries JD, Byron A, Humphries MJ: Integrin ligands at a glance. J Cell Sci 2006, 119:3901-3903.

35. Niu G, Chen X: Why integrin as a primary target for imaging and therapy. Theranostics 2011, 1:30-47.

36. Meyer V, Unsicker K: Cell density and exogenous CNTF affect CNTF mRNA levels in glial cell cultures. Neuroreport 1994, 5:1946-1948.

37. Milner R, Relvas JB, Fawcett J, ffrench-Constant C: Developmental regulation of alphav integrins produces functional changes in astrocyte behavior. Mol Cell Neurosci 2001, 18:108-118.

38. Plow EF, Haas TK, Zhang L, Loftus J, Smith JW: Ligand binding to integrins. J Biochem 2000, 275:21785-21788.

39. Takada Y, Ye X, Simon S: The integrins. Genome Biol 2007, 8:215-215.

40. Xue GP, Calvert RA, Morris RJ: Expression of the neuronal surface glycoprotein Thy- 1 is under post-transcriptional control, and is spatially regulated, in the developing olfactory system. Development 1990, 109:851-864.

41. Barlow JZ, Huntley GW: Developmentally regulated expression of Thy- 1 in structures of the mouse sensory-motor system. J Comp Neurol 2000, 421:215-233.

42. Seiffert D, Iruela-Arispe ML, Sage EH, Loskutoff DJ: Distribution of vitronectin mRNA during murine development. Dev Dyn 1995, 203:71-79.

43. Tom VJ, Doller CM, Malouf AT, Silver J: Astrocyte-associated fibronectin is critical for axonal regeneration in adult white matter. J Neurosci 2004, 24:9282-9290.

44. Mitra SK, Hanson DA, Schlaepfer DD: Focal adhesion kinase: in command and control of cell motility. Nat Rev Mol Cell Biol 2005, 6:56-68.

45. Saleem S, Li J, Yee S-P, Fellows GF, Goodyer CG, Wang R: beta1 integrin/ FAK/ERK signalling pathway is essential for human fetal islet cell differentiation and survival. J Pathol 2009, 219:182-192.

46. Dolfi F, Garcia-Guzman M, Ojaniemi M, Nakamura H, Matsuda M, Vuori K The adaptor protein Crk connects multiple cellular stimuli to the JNK signaling pathway. Proc Natl Acad Sci USA 1998, 95:15394-15399.

47. Oktay M, Wary KK, Dans M, Birge RB, Giancotti FG: Integrin-mediated activation of focal adhesion kinase is required for signaling to Jun $\mathrm{NH}_{2}$ terminal kinase and progression through the $\mathrm{G} 1$ phase of the cell cycle. J Cell Biol 1999, 145:1461-1469.

48. Aikawa R, Nagai T, Kudoh S, Zou Y, Tanaka M, Tamura M, Akazawa H, Takano $H$, Nagai R, Komuro I: Integrins play a critical role in mechanical stress-induced p38 MAPK activation. Hypertension 2002, 39:233-238.

49. Ihle JN: STATs: signal transducers and activators of transcription. Cell 1996, 84:331-334.

50. Darnell JE: STATs and gene regulation. Science 1997, 277:1630-1635.

51. Lim CP, Cao X: Serine phosphorylation and negative regulation of Stat3 by JNK. J Biol Chem 1999, 274:31055-31061.

52. Schust J, Sperl B, Hollis A, Mayer TU, Berg T: Stattic: a small-molecule inhibitor of STAT3 activation and dimerization. Chem Biol 2006, 13:1235-1242.

53. Carroll $\mathrm{P}$, Sendtner $\mathrm{M}$, Meyer $\mathrm{M}$, Thoenen $\mathrm{H}$ : Rat ciliary neurotrophic factor (CNTF): gene structure and regulation of mRNA levels in glial cell cultures. Glia 1993, 9:176-187.

54. Zhang Z, Fuller GM: Interleukin 1beta inhibits interleukin 6-mediated rat gamma fibrinogen gene expression. Blood 2000, 96:3466-3472.

55. Niu GL, Wright KL, Huang M, Song LX, Haura E, Turkson J, Zhang SM, Wang TH, Sinibaldi D, Coppola D, Heller R, Ellis LM, Karras J, Bromberg J, Pardoll D, Jove R, Yu H: Constitutive Stat3 activity up-regulates VEGF expression and tumor angiogenesis. Oncogene 2002, 21:2000-2008.

56. Sumimoto $H$, Imabayashi $F$, Iwata $T$, Kawakami $Y$ : The BRAF-MAPK signaling pathway is essential for cancer-immune evasion in human melanoma cells. J Exp Med 2006, 203:1651-1656.

57. Kang SS, Keasey MP, Cai J, Hagg T: Loss of Neuron-Astroglial Interaction Rapidly Induces Protective CNTF Expression after Stroke in Mice. J Neurosci 2012, 32:9277-9287.

58. Yu H, Kortylewski M, Pardoll D: Crosstalk between cancer and immune cells: role of STAT3 in the tumour microenvironment. Nat Rev Immunol 2007, 7:41-51.
59. Doetsch F, Petreanu L, Caille I, Garcia-Verdugo J-M, Alvarez-Buylla A: EGF converts transit-amplifying neurogenic precursors in the adult brain into multipotent stem cells. Neuron 2002, 36:1021-1034

60. Baeten KM, Akassoglou K: Extracellular matrix and matrix receptors in blood-brain barrier formation and stroke. Dev Neurobiol 2011, 71:1018-1039.

61. Milner R, Huang X, Wu J, Nishimura S, Pytela R, Sheppard D, ffrenchConstant C: Distinct roles for astrocyte alphavbeta5 and alphavbeta8 integrins in adhesion and migration. J Cell Sci 1999, 112(Pt 23):4271-4279.

62. Avalos AM, Valdivia AD, Muñoz N, Herrera-Molina R, Tapia JC, Lavandero S, Chiong M, Burridge K, Schneider P, Quest AFG, Leyton L: Neuronal Thy-1 induces astrocyte adhesion by engaging syndecan- 4 in a cooperative interaction with alphavbeta3 integrin that activates PKCalpha and RhoA. J Cell Sci 2009, 122:3462-3471.

63. Al-Ahmad AJ, Lee B, Saini M, Bix GJ: Perlecan domain V modulates astrogliosis In vitro and after focal cerebral ischemia through multiple receptors and increased nerve growth factor release. Glia 2011, 59:1822-1840

64. Corley SM, Ladiwala U, Besson A, Yong WW: Astrocytes attenuate oligodendrocyte death in vitro through an alpha(6) integrin-laminin -dependent mechanism. Glia 2001, 36:281-294.

65. Colombatti M, Moretto G, Tommasi M, Fiorini E, Poffe O, Colombara M, Tanel R, Tridente G, Ramarli D: Human MBP-specific T cells regulate IL-6 gene expression in astrocytes through cell-cell contacts and soluble factors. Glia 2001, 35:224-233.

66. Sasamoto A, Nagino M, Kobayashi S, Naruse K, Nimura Y, Sokabe M: Mechanotransduction by integrin is essential for IL- 6 secretion from endothelial cells in response to uniaxial continuous stretch. Am J Physio Cell Physiol 2005, 288:C1012-C1022.

67. Gall CM, Pinkstaff JK, Lauterborn JC, Xie Y, Lynch G: Integrins regulate neuronal neurotrophin gene expression through effects on voltagesensitive calcium channels. Neuroscience 2003, 118:925-940.

68. Guo S, Kim WJ, Lok J, Lee S-R, Besancon E, Luo B-H, Stins MF, Wang X, Dedhar S, Lo EH: Neuroprotection via matrix-trophic coupling between cerebral endothelial cells and neurons. Proc Natl Acad Sci USA 2008, 105:7582-7587.

69. Blumbach K, Niehoff A, Belgardt BF, Ehlen HWA, Schmitz M, Hallinger R, Schulz J-N, Brüning JC, Krieg T, Schubert M, Gullberg D, Eckes B: Dwarfism in mice lacking collagen-binding integrins $\alpha 2 \beta 1$ and $\alpha 11 \beta 1$ is caused by severely diminished IGF-1 levels. J Biol Chem 2012, 287:6431-6440.

70. Lichtenstein MP, Madrigal JLM, Pujol A, Galea E: JNK/ERK/FAK mediate promigratory actions of basic fibroblast growth factor in astrocytes via CCL2 and COX2. Neurosignals 2012, 20:86-102

71. Leyton L, Schneider P, Labra CV, Rüegg C, Hetz CA, Quest AF, Bron C: Thy-1 binds to integrin beta(3) on astrocytes and triggers formation of focal contact sites. Curr Biol 2001, 11:1028-1038.

72. Grant SG, Karl KA, Kiebler MA, Kandel ER: Focal adhesion kinase in the brain: novel subcellular localization and specific regulation by Fyn tyrosine kinase in mutant mice. Genes Dev 1995, 9:1909-1921.

73. Bartos JA, Ulrich JD, Li H, Beazely MA, Chen Y, Macdonald JF, Hell JW: Postsynaptic clustering and activation of Pyk2 by PSD-95. J Neurosci 2010, 30:449-463.

74. Stevens GR, Zhang C, Berg MM, Lambert MP, Barber K, Cantallops I, Routtenberg A, Klein WL: CNS neuronal focal adhesion kinase forms clusters that co-localize with vinculin. J Neurosci Res 1996, 46:445-455

75. Serpente N, Birling MC, Price J: The regulation of the expression, phosphorylation, and protein associations of pp125FAK during rat brain development. Mol Cell Neurosci 1996, 7:391-403.

76. Shimamura N, Matchett G, Yatsushige H, Calvert JW, Ohkuma H, Zhang J: Inhibition of integrin alphavbeta3 ameliorates focal cerebral ischemic damage in the rat middle cerebral artery occlusion model. Stroke 2006, 37:1902-1909.

77. Parsons JT, Martin KH, Slack JK, Boerner SA, Martin CC: Integrin Signaling Pathway. Sci Signal 2011, 4:ec138-ec138.

78. Legate KR, Montañez E, Kudlacek O, Fässler R: ILK, PINCH and parvin: the tIPP of integrin signalling. Nat Rev Mol Cell Biol 2006, 7:20-31.

79. Kuhlbrodt K, Herbarth B, Sock E, Hermans-Borgmeyer I, Wegner M: Sox10, a novel transcriptional modulator in glial cells. J Neurosci 1998, 18:237-250. 
80. Kordes U, Hagel C: Expression of SOX9 and SOX10 in central neuroepithelial tumor. J Neurooncol 2006, 80:151-155.

81. Paintlia MK, Paintlia AS, Singh AK, Singh I: S-nitrosoglutathione induces ciliary neurotrophic factor expression in astrocytes that has implication to protect CNS under pathological conditions. J Biochem 2012, 288(6):3831-3843

82. Sengupta TK, Talbot ES, Scherle PA, Ivashkiv LB: Rapid inhibition of interleukin- 6 signaling and Stat 3 activation mediated by mitogenactivated protein kinases. Proc Natl Acad Sci USA 1998, 95:11107-11112.

83. Decker T, Kovarik P: Serine phosphorylation of STATs. Oncogene 2000, 19:2628-2637.

84. Zhang X, Blenis J, Li HC, Schindler C, Chen-Kiang S: Requirement of serine phosphorylation for formation of STAT-promoter complexes. Science 1995, 267:1990-1994.

85. Nelson ED, Kavalali ET, Monteggia LM: MeCP2-dependent transcriptional repression regulates excitatory neurotransmission. Curr Biol 2006, 16:710-716.

86. Chahrour M, Jung SY, Shaw C, Zhou X, Wong STC, Qin J, Zoghbi HY: $\mathrm{MeCP} 2$, a key contributor to neurological disease, activates and represses transcription. Science 2008, 320:1224-1229.

87. Kahn MA, Huang CJ, Caruso A, Barresi V, Nazarian R, Condorelli DF, de Vellis $\mathrm{J}$ : Ciliary neurotrophic factor activates JAK/Stat signal transduction cascade and induces transcriptional expression of glial fibrillary acidic protein in glial cells. J Neurochem 1997, 68:1413-1423.

88. Wishingrad MA, Koshlukova S, Halvorsen SW: Ciliary neurotrophic factor stimulates the phosphorylation of two forms of STAT3 in chick ciliary ganglion neurons. J Biol Chem 1997, 272:19752-19757.

89. Bonni A, Sun Y, NadalVicens M, Bhatt A, Frank DA, Rozovsky I, Stahl N, Yancopoulos GD, Greenberg ME: Regulation of gliogenesis in the central nervous system by the JAK-STAT signaling pathway. Science 1997, 278:477-483.

90. Askvig JM, Lo DY, Sudbeck AW, Behm KE, Leiphon $L$, Watt JA: Inhibition of the Jak-STAT pathway prevents CNTF-mediated survival of axotomized oxytocinergic magnocellular neurons in organotypic cultures of the rat supraoptic nucleus. Exp Neurol 2013, 240:75-87.

91. Bechstein M, Häussler U, Neef M, Hofmann H-D, Kirsch M, Haas CA: CNTFmediated preactivation of astrocytes attenuates neuronal damage and epileptiform activity in experimental epilepsy. Exp Neurol 2012, 236:141-150.

92. Ozog MA, Bechberger JF, Naus CCG: Ciliary neurotrophic factor (CNTF) in combination with its soluble receptor (CNTFRalpha) increases connexin43 expression and suppresses growth of $\mathrm{C} 6$ glioma cells. Cancer Res 2002, 62:3544-3548.

93. Sudoh S, Kawakami H, Ohta M, Nakamura S: Ciliary neurotrophic factor induced-increase in beta-amyloid precursor protein mRNA in rat C6 glioma cells. Biochem Biophys Res Commun 1994, 204:391-398.

94. Schuster B, Kovaleva M, Sun Y, Regenhard P, Matthews V, Grotzinger J, RoseJohn S, Kallen KJ: Signaling of human ciliary neurotrophic factor (CNTF) revisited - The interleukin-6 receptor can serve as an alpha-receptor for CNTF. J Biol Chem 2003, 278:9528-9535.

95. Wegrzyn J, Potla R, Chwae Y-J, Sepuri, Naresh BV, Zhang Q, Koeck T, Derecka M, Szelag M, Gornicka A: Function of mitochondrial Stat3 in cellular respiration. Sci Signal 2009, 323:793.

96. Gough DJ, Corlett A, Schlessinger K, Wegrzyn J, Larner AC, Levy DE: Mitochondrial STAT3 supports Ras-dependent oncogenic transformation. Science 2009, 324:1713-1716.

97. Szczepanek K, Chen Q, Larner AC, Lesnefsky EJ: Cytoprotection by the modulation of mitochondrial electron transport chain: The emerging role of mitochondrial STAT3. Mitochondrion 2012, 12:180-189.

98. Sarafian TA, Montes C, Imura T, Qi J, Coppola G, Geschwind DH, Sofroniew MV: Disruption of astrocyte STAT3 signaling decreases mitochondrial function and increases oxidative stress in vitro. PLOS One 2010, 5:e9532.

99. Saleh A, Roy Chowdhury SK, Smith DR, Balakrishnan S, Tessler L, Martens C, Morrow D, Schartner E, Frizzi KE, Calcutt NA, Fernyhough P: Ciliary neurotrophic factor activates NF-KB to enhance mitochondrial bioenergetics and prevent neuropathy in sensory neurons of streptozotocin-induced diabetic rodents. Neuropharmacology 2013, 65:65-73.

100. Weber RJ, Hill JM, Pert CB: Regional distribution and density of Thy 1.1 in rat brain and its relation to subpopulations of neurons. I Neuroimmunol 1988, 17:137-145.
101. Liesi P, Fried G, Stewart RR: Neurons and glial cells of the embryonic human brain and spinal cord express multiple and distinct isoforms of laminin. J Neurosci Res 2001, 64:144-167.

102. Müller S, Chakrapani BPS, Schwegler H, Hofmann H-D, Kirsch M: Neurogenesis in the dentate gyrus depends on ciliary neurotrophic factor and signal transducer and activator of transcription 3 signaling. Stem Cells 2009, 27:431-441.

103. Murase S-I, Horwitz AF: Deleted in colorectal carcinoma and differentially expressed integrins mediate the directional migration of neural precursors in the rostral migratory stream. J Neurosci 2002, 22:3568-3579.

104. Emsley JG, Hagg t: alpha6beta1 integrin directs migration of neuronal precursors in adult mouse forebrain. Exp Neurol 2003, 183:273-285.

105. Belvindrah R, Hankel S, Walker J, Patton BL, Müller U: Beta1 integrins control the formation of cell chains in the adult rostral migratory stream. J Neurosci 2007, 27:2704-2717.

106. Shen Q, Wang Y, Kokovay E, Lin G, Chuang S-M, Goderie SK, Roysam B, Temple S: Adult SVZ stem cells lie in a vascular niche: a quantitative analysis of niche cell-cell interactions. Cell Stem Cell 2008, 3:289-300.

107. Staquicini Fl, Dias-Neto E, Li J, Snyder EY, Sidman RL, Pasqualini R, Arap W: Discovery of a functional protein complex of netrin-4, laminin gamma1 chain, and integrin alpha6beta1 in mouse neural stem cells. Proc Natl Acad Sci USA 2009, 106:2903-2908.

108. Mobley AK, Mccarty JH: $\beta 8$ integrin is essential for neuroblast migration in the rostral migratory stream. Glia 2011, 59:1579-1587.

109. Maxfield SR, Moulder K, Koning F, Elbe A, Stingl G, Coligan JE, Shevach EM, Yokoyama WM: Murine T cells express a cell surface receptor for multiple extracellular matrix proteins. Identification and characterization with monoclonal antibodies. J Exp Med 1989, 169:2173-2190.

110. Piali L, Hammel P, Uherek C, Bachmann F, Gisler RH, Dunon D, Imhof BA: CD31/PECAM-1 is a ligand for alpha $v$ beta 3 integrin involved in adhesion of leukocytes to endothelium. J Cell Biol 1995, 130:451-460.

111. Sonnenberg A, Linders CJ, Modderman PW, Damsky CH, Aumailley M, Timpl R: Integrin recognition of different cell-binding fragments of laminin ( $\mathrm{P} 1$, E3, E8) and evidence that alpha 6 beta 1 but not alpha 6 beta 4 functions as a major receptor for fragment E8. J Cell Biol 1990, 110:2145-2155.

112. Noto K, Kato K, Okumura K, Yagita H: Identification and functional characterization of mouse CD29 with a mAb. Int Immunol 1995, 7:835-842.

113. Sugiyama M, Speight PM, Prime SS, Watt FM: Comparison of integrin expression and terminal differentiation capacity in cell lines derived from oral squamous cell carcinomas. Carcinogenesis 1993, 14:2171-2176.

114. Sangaletti S, Di Carlo E, Gariboldi S, Miotti S, Cappetti B, Parenza M, Rumio C, Brekken RA, Chiodoni C, Colombo MP: Macrophage-derived SPARC bridges tumor cell-extracellular matrix interactions toward metastasis. Cancer Res 2008, 68:9050-9059.

115. Bennett BL, Sasaki DT, Murray BW, O'Leary EC, Sakata ST, Xu W, Leisten JC, Motiwala A, Pierce S, Satoh Y, Bhagwat SS, Manning AM, Anderson DW: SP600125, an anthrapyrazolone inhibitor of Jun N-terminal kinase. Proc Natl Acad Sci USA 2001, 98:13681-13686.

116. Saklatvala J, Rawlinson L, Waller RJ, Sarsfield S, Lee JC, Morton LF, Barnes MJ, Farndale RW: Role for p38 mitogen-activated protein kinase in platelet aggregation caused by collagen or a thromboxane analogue. J Biol Chem 1996, 271:6586-6589.

117. Favata MF: Identification of a Novel Inhibitor of Mitogen-activated Protein Kinase Kinase. J Biol Chem 1998, 273:18623-18632.

118. Slack-Davis JK, Martin KH, Tilghman RW, Iwanicki M, Ung EJ, Autry C, Luzzio MJ, Cooper B, Kath JC, Roberts WG, Parsons JT: Cellular characterization of a novel focal adhesion kinase inhibitor. J Biol Chem 2007, 282:14845-14852.

119. Li JJ, Dong Z, Dawson Ml, Colburn NH: Inhibition of tumor promoterinduced transformation by retinoids that transrepress AP-1 without transactivating retinoic acid response element. Cancer Res 1996, 56:483-489.

120. Huang C, Ma W-Y, Dawson MI, Rincon M, Flavell RA, Dong Z: Blocking activator protein-1 activity, but not activating retinoic acid response element, is required for the antitumor promotion effect of retinoic acid. Proc Natl Acad Sci USA 1997, 94:5826-5830.

121. Seaman WE, Wofsy D, Greenspan JS, Ledbetter JA: Treatment of autoimmune MRL/Ipr mice with monoclonal antibody to Thy-1.2: 
a single injection has sustained effects on lymphoproliferation and renal disease. J Immunol 1983, 130:1713-1718.

122. Kiuchi N, Nakajima K, Ichiba M, Fukada T, Narimatsu M, Mizuno K, Hibi M, Hirano T: STAT3 is required for the gp130-mediated full activation of the c-myc gene. J Exp Med 1999, 189:63-73.

123. Adach-Kilon A, Swiatek-Machado K, Kaminska B, Dabrowski M: Signal transducer and activator of transcription 1 (Stat1) maintains basal mRNA expression of pro-survival stat3-target genes in glioma C6 cells. J Cell Biochem 2011, 112:3685-3694.

doi:10.1186/1478-811X-11-35

Cite this article as: Keasey et al:: Inhibition of a novel specific neuroglial integrin signaling pathway increases STAT3-mediated CNTF expression. Cell Communication and Signaling 2013 11:35.

\section{Submit your next manuscript to BioMed Central and take full advantage of:}

- Convenient online submission

- Thorough peer review

- No space constraints or color figure charges

- Immediate publication on acceptance

- Inclusion in PubMed, CAS, Scopus and Google Scholar

- Research which is freely available for redistribution 